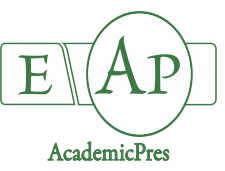

Rusu T et al. (2021)

Notulae Botanicae Horti Agrobotanici Cluj-Napoca

Volume 49, Issue 3, Article number 12427

DOI: $10.15835 /$ nbha49312427

Review Article

\title{
Influence of environmental and nutritional factors on the development of lettuce (Lactuca sativa L.) microgreens grown in a hydroponic system: A review
}

\author{
Teodor RUSU ${ }^{1 *}$, Paula I. MORARU ${ }^{1}$, Olimpia S. MINTAS ${ }^{2}$ \\ ${ }^{1}$ University of Agricultural Sciences and Veterinary Medicine Cluj-Napoca, 3-5 Manastur Street, 400372, Cluj-Napoca, \\ Romania; trusu@usamvcluj.ro (*corresponding author);paulaioana.moraru@usamvcluj.ro \\ ${ }^{2}$ University of Oradea, Faculty of Environmental Protection, 26, B-rd Gen. Magheru, 410057, Oradea, \\ Romania;buzasiu@yahoo.com
}

\begin{abstract}
Lettuce microgreens are one of the most popular vegetables due to them being perceived as a "healthy food", with high concentrations of nutrients, beneficial vitamins, and minerals. With a short vegetation period, they can be cultivated with minimum investment, and they are increasingly accepted by consumers, as they are healthy and easy to prepare. Lettuce has high ecological plasticity, but, despite this, its phenotypic expression, morphology, physiology, and anatomy are significantly influenced by environmental conditions. Lettuce microgreens contain higher quantities of phytonutrients and minerals and lower quantities of nitrates at the early stage of development than at the completely developed stage. The environmental conditions that influence the development of lettuce microgreens (and their quality) in a hydroponic system are as follows (average ideal values): light $(400 \mathrm{~W})$, photoperiodicity $(12 \mathrm{~h})$, light intensity $\left(400 \mu \mathrm{mol} \mathrm{m} \mathrm{m} \mathrm{s}^{-1}\right)$, colour spectrum $(440-460 \mathrm{~nm})$, temperature $\left(20 \pm 2{ }^{\circ} \mathrm{C}\right)$, and humidity $(80 \pm 5 \%)$. The nutritional solution in a hydroponic system must be carefully monitored, by checking certain essential parameters such as the following (average ideal values): $\mathrm{pH}(6.3 \pm 0.4)$, electrical conductivity $(1.8 \pm 0.2 \mathrm{mS})$, dissolved oxygen $\left(6 \mathrm{mg} \mathrm{L}^{-1}\right)$, and temperature $\left(18 \pm 2{ }^{\circ} \mathrm{C}\right)$. The analysis of expert literature reveals that there is a need to establish certain protocols for cultivating microgreens in hydroponic systems, to minimize the factors that can negatively influence the plants, in order to obtain higher concentrations of active substances.
\end{abstract}

Keywords: hydroponic system; lettuce; microgreens; review

\section{Introduction}

Lettuce (Lactuca sativa L.), belonging to the Asteraceae family, is one of the most popular vegetables, especially used in salads; it is consumed in ever-increasing quantities, as it is perceived as a healthy food (Dupont et al., 2000). Additionally, lettuce is increasingly accepted by consumers, as it is healthy and easy to prepare (Teng et al., 2021). The most used parts are the leaves, followed by the stems (for juice) and seeds (for seed mixes). Lettuce is cultivated for its head, which is usually consumed fresh, in different salads, and during the last years as microgreens (cotyledon phase) (Turner et al., 2020). Microgreens have become a culinary trend, due to the relative ease of obtaining them and their promotion sites and production equipment, as well as due

Received: 03 Jul 2021. Received in revised form: 19 Aug 2021. Accepted: 23 Aug 2021. Published online: 03 Sep 2021.

From Volume 49, Issue 1, 2021, Notulae Botanicae Horti Agrobotanici Cluj-Napoca journal uses article numbers in place of the traditional method of continuous pagination through the volume. The journal will continue to appear quarterly, as before, with four annual numbers. 
to research indicating that microgreens may have 4-40 times (Xiao et al., 2012) the amounts of some nutrients and vitamins as the mature plants. Lettuce microgreens can provide higher concentrations of phytonutrients (ascorbic acid, $\beta$-carotene, $\alpha$-tocopherol, and phylloquinone) (Kyriacou et al., 2016) and minerals (Ca, Mg, Fe, $\mathrm{Mn}, \mathrm{Zn}, \mathrm{Se}$, and Mo) than their mature-leaf counterparts (Pinto et al., 2015). It is important in the human diet due to its contents of vitamins, mineral salts and nutrients (Kim et al., 2016). Due to its short vegetation period and ability to withstand cold weather (Ciuta et al., 2020), it can be cultivated in any season, with minimum investment.

Despite all these advantages of lettuce consumption, there are no clear protocols for the high-quality production of lettuce microgreens in hydroponic conditions. Therefore, this literature review is a systematic approach to organizing the information concerning lettuce, with the evaluation of the general environmental and nutritional conditions, particularly for microgreens in hydroponic systems, in order to identify the possibilities for the control and regulation of their quantity and quality. The purpose of this literature review is to determine all the influencing factors, which would allow the elaboration of a protocol for testing platforms for growing lettuce microgreens hydroponically.

\section{Physico-chemical properties of lettuce}

Lettuce has a taproot that may reach up to $60-70 \mathrm{~cm}$. Numerous other roots sprout laterally, which can be up to 10-15 cm long. The leaves develop differently, according to type; first, a leaf rosette is developed, and later, certain types also develop a loose, less stuffed head. Lettuce microgreens are harvested when the seedleaves have fully expanded and before true leaves have emerged (Reed et al., 2018). Leaves are usually coloured vividly, and they vary among greens, reds or yellows. They are short petiolate, corrugated, and the edges can be smooth or serrated. As it develops, the plant forms a head with different shapes and sizes, according to type. In the case of the types with heads, the leaves inside them are etiolated and softer than the ones from the rosette. The head phase lasts 10-15 days, after which the plants develop flowering stems. A flowering stem is highly branched and has a capitulum with yellow flowers on its top. The stem appears 45-65 days after the lettuce is sown and can reach a height of 1-1.2 m (Ciofu et al., 2004). The flowers are grouped in ovoid cylindrical capitula; they are ligulate or tubular, small and yellow. The fruit is small and may have a white-silver, black or brown colour, as well as a pappus.

Lettuce has a short vegetation period. The microgreens can be harvested at around 15 days, the heads can be harvested at 45-50 days, and after around 120 days, the seeds can be harvested. Lettuce can be stored in cold rooms, at temperatures of $0-1{ }^{\circ} \mathrm{C}$ and $95 \%$ humidity, for up to $10-12$ days.

Lettuce can be found in a range of colours, sizes and forms, selected upon cultivation according to the tenets desired. Although there have been different systems of classification proposed by different groups of researchers throughout the years (Rodenburg, 1960; Lebeda et al., 2007; Mou, 2008; Güzel et al., 2021), there is no standardized classification system, due to the high genetic and morphological diversity in the types of lettuce (Kim et al., 2016). According to Mou (2008), there are six main lettuce types based upon the leaf shape, size, texture, head formation, and stem type (Kim et al., 2016). They are (1) crisphead lettuce (var. capitata L. nidus jaggeri Helm), (2) butterhead lettuce (var. capitata L. nidus tenerrima Helm), (3) romaine or cos lettuce (var. longifolia Lam., var. romana Hort. in Bailey), (4) leaf or cutting lettuce (var. acephala Alef., syn. var. secalina Alef., syn. var. crispa L.), (5) stem or stalk (Asparagus) lettuce (var. angustana Irish ex Bremer, syn. var. asparagina Bailey, syn. L. angustana Hort. In Vilm.), and (6) Latin lettuce (no scientific name).

The nutritional qualities and properties of healthy foods are attributed to high contents of antioxidant compounds (vitamins A, C and E, carotenoids, and polyphenols), iron and calcium (Romani et al., 2002), folic acid and fibre (Pepe et al., 2015; Sofo et al., 2016; Van Treuren et al., 2018), and anthocyanins and chlorophylls, with anthocyanins being more abundant in red varieties (Liorach et al., 2008). Lettuce is typically low in calories and packed with fibre (Liorach et al., 2008), and the fresh leaves are an excellent source of vitamin A 
and $\beta$-carotene. Just $100 \mathrm{~g}$ of fresh, raw lettuce provides $24 \%$ of the daily recommended intake of vitamin A and $\beta$-carotene, but high quantities of minerals such as iron, calcium, magnesium, and potassium are also present, which are essential for the human body's metabolism.

However, the nutritional value of lettuce varies among the different varieties (Kim et al., 2016). According to Mou and Ryder (2004), the lower nutritional value of some varieties is due to the high closure of their leaves in the head structure, because most of the edible portion of the head structure includes leaves that are not exposed to light (Ryder, 1997). The contents of beta-carotene (provitamin A), Ca, and Fe were higher in the outer leaves than in the inner leaves of a normal lettuce head, while there was little difference in the vitamin $\mathrm{C}$ content between the two classes of leaves. Opening the lettuce head greatly artificially increased the nutrient contents to levels comparable to those for leaf or romaine lettuce. When romaine lettuce leaves were closed, the levels of beta-carotene and vitamin $\mathrm{C}$ dropped to a minimum and the contents of $\mathrm{Ca}$ and Fe were also largely reduced. These results suggest that the lower nutritional value of crisphead lettuce is due to the enclosure of its leaves in the head structure (Mou and Ryder, 2004). Similar results were also obtained by Park et al. (2018), who showed that the total phenolic content was higher in red skirt methanolic extracts, at $64.9 \pm$ $0.3 \mathrm{mg}$ gallic acid $\mathrm{g}^{-1}$, while the phenolic content of green skirt was $49.4 \pm 0.3 \mathrm{mg}$ gallic acid $\mathrm{g}^{-1}$.

\section{General ecological requirements}

Lettuce has high ecological plasticity, but in spite of this, its phenotypic expression, morphology, physiology, and anatomy are significantly influenced by growing conditions.

Light and temperature are considered among the most important environment conditions for the development of lettuce (Ojeda et al., 2012). Solar radiation, especially long-wave red light, is a limiting factor for the germination of lettuce seeds (Hiroshi, 1964; Hegarty and Ross, 2006). Even under conditions of salt stress, seed pretreatment with $\mathrm{CaCl}_{2}, \mathrm{H}_{2} \mathrm{O}_{2}$, and sodium nitroprusside (SNP) led to successful seed germination (Hajihashemi et al., 2020). Temperatures above $24^{\circ} \mathrm{C}$ cause significant changes in the endosperm layer, generating a mechanical force that counteracts and may even inhibit germination (Takeba and Matsubara, 1976; Sung et al., 1997). Takaki and Zaia (1984) showed that these two environmental factors could be correlated, as high temperatures also affect the phytochromes, which are phototransmitters acting on blue and red light, causing an expansion of leaves, reduced germination, and problems with the photoperiod.

Lettuce is a plant without high heat requirements, and it resists cold weather well; its temperature tolerance according to development stage is as follows: At $5-10^{\circ} \mathrm{C}$, seeds germinate and plants begin to sprout 6-10 days after sowing. Lettuce resists temperatures ranging between -5 and $-6^{\circ} \mathrm{C}$, if it is in the rosette phase with 5-6 leaves, and it can also resist temperatures of -2 and $-3{ }^{\circ} \mathrm{C}$ in the phase of head formation and stem development. The best temperature at which for leaves to grow and form heads is around $16-20^{\circ} \mathrm{C}$ (depending on the light intensity), and a temperature ranging between 20 and $22^{\circ} \mathrm{C}$ is needed for the stem and flowers to form (Ciofu et al., 2004). It is important to specify that, at high temperatures, over $25^{\circ} \mathrm{C}$, certain types of lettuce do not sprout, the leaves etiolate, and the head does not form accordingly.

Lettuce needs a lot of light, as sufficient light influences the vegetation period. Lettuce is a long-day plant. Under long-day conditions, it has a short vegetation period and forms flower stems before forming normal heads. Under such conditions, most types form a flowering, branched stem, and flowers are formed on top of them, disposed in calathidium inflorescences. Under short-day conditions $(<12 \mathrm{~h})$, they form a rich foliar apparatus and big heads, which do not quickly progress to floral stems. Types that are less influenced by day length $(12-14 \mathrm{~h})$ have been created.

Lettuce prefers a $\mathrm{pH}$ of 6-7.2; an excessively acid $\mathrm{pH}$ must be avoided. Macroelements are important; phosphorus contributes to speeding up head formation, while potassium promotes the formation of a stuffed head. Nitrate stimulates head growth and increases production. 
Lettuce needs high humidity, especially when it sprouts and when heads are formed. Thus, when it is cultivated on the ground, the best humidity is $70-80 \%$ of the interval of active humidity. Should humidity be low and temperatures high, then the crop yield shall be low. However, excess humidity must also be avoided, as it leads to diseases.

Lettuce must be harvested during cool, but dry, weather because, if the leaves are wet, they can easily become altered.

\section{Main diseases and pests of lettuce}

The most serious threat to microgreens appears to be Pythium (McGehee et al., 2019). The main diseases and pests that can emerge in the lettuce crop are presented in Table 1 (Ciofu et al., 2004). For microgreens, it is very important to prevent the transmission of bacteria or viruses (Misra, 2020). This is because there is no cooking step to kill the bacteria or viruses in the products before they enter microgreen salads. Washing does not necessarily remove them either, so prevention is essential. Microbial biofungicides can be introduced in nutrient solutions through the nutrient film technique or applied in irrigation to prevent Pythium root (McGehee et al., 2019).

Table 1. The main diseases and pests that can damage the lettuce crop

\begin{tabular}{|c|c|c|c|}
\hline No. & $\begin{array}{l}\text { Diseases (1-9) } \\
\text { and pests } \\
(10-14)\end{array}$ & $\begin{array}{l}\text { Scientific } \\
\text { name }\end{array}$ & Description \\
\hline 1 & Lettuce blight & $\begin{array}{l}\text { Bremia } \\
\text { lactucae }\end{array}$ & $\begin{array}{l}\text { It appears both in field crops and in protected spaces, under high } \\
\text { humidity and temperatures ranging between } 10 \text { and } 21^{\circ} \mathrm{C} \text {. This disease } \\
\text { affects the development of lettuce and the quality of the harvest. The } \\
\text { attack can be recognized based on the emergence of yellow angular spots } \\
\text { on the upper part of leaves and of fuzz on their lower parts. }\end{array}$ \\
\hline 2 & Grey mould & Botrytis cinere & $\begin{array}{c}\text { The attack takes the form of grey-brown to brown-orange spots, with a } \\
\text { watery appearance, located on the leaf veins or on the leaves from the } \\
\text { base. This disease can rapidly affect the entire plant, even after harvest. If } \\
\text { it is not treated in time, plants become discoloured and die. }\end{array}$ \\
\hline 3 & White mould & $\begin{array}{c}\text { Sclerotinia } \\
\text { sclerotiorum }\end{array}$ & $\begin{array}{l}\text { It is the most aggressive ground disease of lettuce. It attacks the stem and } \\
\text { the leaves from the base of the plant, and it can lead to the rotting of the } \\
\text { collet but also of the leaves from the base, close to the ground. }\end{array}$ \\
\hline 4 & $\begin{array}{c}\text { Falling of small } \\
\text { plants }\end{array}$ & $\begin{array}{l}\text { Pythium } \\
\text { ultimum }\end{array}$ & $\begin{array}{c}\text { This disease especially attacks seedlings, and it emerges under conditions } \\
\text { of high soil humidity and temperatures over } 20^{\circ} \mathrm{C} \text {. The fungus attacks } \\
\text { the seedlings around the collet, towards the root and the stem, leading to } \\
\text { their collapse. }\end{array}$ \\
\hline 5 & $\begin{array}{c}\text { Lettuce } \\
\text { anthracnose }\end{array}$ & $\begin{array}{l}\text { Microdochium } \\
\text { panattonianum }\end{array}$ & $\begin{array}{c}\text { The signs of the attack include spots with a humid aspect, on both sides } \\
\text { of leaves, yellow on the inside and brown on the outside, } 2-3 \mathrm{~mm} \text { long. } \\
\text { The spots grow step by step; they become irregular and lead to leaf } \\
\text { dryness and necrosis. }\end{array}$ \\
\hline 6 & Lettuce fusarium & $\begin{array}{l}\text { Fusarium } \\
\text { oxysporum }\end{array}$ & $\begin{array}{c}\text { This disease attacks even from the seedling phase, and the wooden } \\
\text { vassals of roots become red to brown, while leaves become yellow; they } \\
\text { become discoloured and die. Plants affected by fusarium cannot form } \\
\text { heads. }\end{array}$ \\
\hline 7 & Lettuce mildew & $\begin{array}{l}\text { Golovinomyces } \\
\text { cichoracearum }\end{array}$ & $\begin{array}{l}\text { This disease especially attacks mature leaves and can be recognized } \\
\text { based on the emergence of a white powder on both sides of leaves. } \\
\text { Subsequently, affected leaves lose colour and deform. }\end{array}$ \\
\hline 8 & Cercosporiosis & $\begin{array}{l}\text { Cercospora } \\
\text { longissima }\end{array}$ & $\begin{array}{l}\text { The attack can be recognized based on the emergence of brown oval } \\
\text { spots, with a white centre, with a diameter of } 1 \mathrm{~cm} \text {, and if temperatures } \\
\text { are high }\left(25-35^{\circ} \mathrm{C}\right) \text {, the spots increase and affect a great part of leaves. }\end{array}$ \\
\hline
\end{tabular}




\begin{tabular}{|c|c|c|c|}
\hline 9 & Verticillium & $\begin{array}{c}\text { Verticillium } \\
\text { dahliae }\end{array}$ & $\begin{array}{l}\text { The attack appears at the plant base, and leaves become yellow and fade, } \\
\text { but they remain attached to the head. The root tissues can turn different } \\
\text { colours (brown, black, and green), appearing as stripes. }\end{array}$ \\
\hline 10 & Gray limax & $\begin{array}{c}\text { Deroceras } \\
\text { agreste }\end{array}$ & $\begin{array}{l}\text { This pest mostly attacks at night or in rainy weather, and it generally } \\
\text { takes shelter in the ground. The attack can be recognized based on the } \\
\text { presence of holes in the centre and on the leaf edges. }\end{array}$ \\
\hline 11 & Black flea & Phyllotreta atra & $\begin{array}{c}\text { It attacks leaves but also flowers and seeds. In a massive attack, poorly } \\
\text { developed plants can be entirely destroyed. }\end{array}$ \\
\hline 12 & Wireworms & Agriotes spp. & $\begin{array}{c}\text { They attack lettuce crops both in the field and in greenhouses, and they } \\
\text { have a generation every } 4 \text { or } 5 \text { years. }\end{array}$ \\
\hline 13 & Cabbage fly & $\begin{array}{l}\text { Aleyrodes } \\
\text { brassicae }\end{array}$ & $\begin{array}{c}\text { This pest attacks the lettuce leaves; the plants affected turn yellow, and } \\
\text { their development is halted. }\end{array}$ \\
\hline 14 & Cucumber beetle & Aphis gossypii & $\begin{array}{l}\text { They suck the cell sap, and affected leaves lose colour, deform, or } \\
\text { become dry. }\end{array}$ \\
\hline
\end{tabular}

\section{Hydroponic environmental conditions}

Under hydroponic conditions, microgreens reach harvest maturity fast, which allows many crop cycles per year. The study of plants in controlled environments facilitates the understanding of factors that influence their development, especially the active principles of their vegetative organs. The complexity of these types of studies results from the fact that hydroponic microgreens are influenced by a great number of environment and nutritional factors, and these must therefore be correlated and analysed in detail in order to develop appropriate cultivation protocols (Zheljazkov et al., 2012; Mbarki et al., 2020). This leads to the improvement of the quality indices, purity, consistency, bioactivity, and biomass of products, on a commercial scale (Hayden, 2006). A hydroponic crop offers greater control and flexibility for the crop environment than a field crop, through the specifications of the system used (Sheikh, 2006; Cruz et al., 2012; Van Treuren et al., 2018).

The biochemical profile of plants is an indicator of their development conditions. The primary metabolism of plants is responsible for their survival and produces metabolites such as sugars, amino acids, vitamins, etc. (Giurgiu, 2016). The secondary metabolism of plants is not vital for survival, but the resulting metabolites impart colour, taste and smell to products, play defensive roles, etc., and they are valued in the pharmaceutical, food and cosmetic industries (Isah et al., 2018). The concentrations of these substances fluctuate a lot because of factors that stimulate secondary metabolism. At the same time, the metabolites differ from one species to another and even within the same species (based on the development phase). The factors that influence the accumulation of bioactive substances are wide-ranging, but they can be grouped in two categories: factors of biotic and abiotic stress (Giurgiu, 2016; Lenzi et al., 2019).

The results obtained highlight the possibility of exploiting genetic biodiversity in order to obtain tailored microgreens with the desired nutritional profiles, with particular regard to mineral nutrients and bioactive compounds (Paradiso et al., 2018; Bian et al., 2020; Ghoora et al., 2020). Functionally, phytonutrient-packed and principally raw food is in high demand (Treadwell et al., 2011). Microgreens constitute such a novel functional food that combines high sensory and bioactive value (El-Nakhel et al., 2020) but also a dense phytochemical content.

Influence of environmental conditions on the quantity and quality of microgreen production in hydroponic system

The environmental conditions that influence the development of plants in a hydroponic system are light (photoperiodicity, light intensity, colour spectrum, and position), temperature, and humidity.

The light conditions have a strong influence on the development of lettuce microgreens, as well as on the biosynthesis and accumulation of chemical compounds (Lin et al., 2013). Light systems with LEDs (lightemitting diodes) have important advantages over traditional ones due to their spectral composition, durability, 
wavelength specificity, low radiant heat, and energetic efficiency (Urrestarazu et al., 2016). LEDs are important lamp types because the concentration of the light spectrum they emit can be changed to provide plants at various developmental stages with the required light spectrum (Olle and Alsiòa, 2019). The quality effects of the light spectrum on the production features and the influence on the contents of bioactive compounds in lettuce are well-known (Ohashi-Kaneko et al., 2007; Samuolienè et al., 2017). The photoresponses of antioxidant compounds suggest that the photoprotective mechanism is stimulated by both light-dosedependent and wavelength-dependent reactions (Carvalho and Folta, 2016; Samuoliene et al., 2016) Lettuce growth is influenced by light colour (Table 2; Olle and Alsiòa, 2019). Far-red lighting increases the number of leaves, elongates the leaves, and promotes the growth of the lettuce, resulting in taller plants (Yuyao and Krishna, 2021).

Table 2. The effect of light colour on growth of lettuce

\begin{tabular}{|c|c|c|c|c|}
\hline No. & Lactuca sativa L. & Reference & Light colour & Effect on growth \\
\hline 1 & Lettuce-Green Salad Bowl & $\begin{array}{c}\text { Legendre and } \\
\text { van Iersel } \\
(2021)\end{array}$ & $\begin{array}{l}\text { Far-red, } 700- \\
\quad 800 \mathrm{~nm}\end{array}$ & $\begin{array}{l}\text { Increasing supplemental far-red light increased leaf length } \\
\text { and width, which was associated with increased projected } \\
\text { canopy size }\end{array}$ \\
\hline 2 & $\begin{array}{l}\text { Green leaf lettuce } \\
\text { (Lobjoits green cos) and } \\
\text { red leaf lettuce }\end{array}$ & $\begin{array}{l}\text { Viršilè et al. } \\
\qquad(2020)\end{array}$ & $\begin{array}{l}\text { Green, } \\
510 \mathrm{~nm}\end{array}$ & $\begin{array}{c}\text { Green light had reasonable impact on the contents of } \\
\text { nutritive primary metabolites in red and green leaf lettuce }\end{array}$ \\
\hline 3 & $\begin{array}{l}\text { Lettuce-var. foliosum cv. } \\
\text { 'Dubacek' and cv. } \\
\text { 'Michalina' }\end{array}$ & $\begin{array}{l}\text { Sergejeva et al. } \\
\quad(2018)\end{array}$ & Blue, $440 \mathrm{~nm}$ & $\begin{array}{c}\text { Compact plant morphology; impact of illumination } \\
\text { source on the dry matter content significantly depended } \\
\text { on cultivar and sampling time }\end{array}$ \\
\hline 4 & Lettuce-Frillice Crisp & $\begin{array}{l}\text { Pinho et al. } \\
(2017)\end{array}$ & $\begin{array}{c}\text { Far red, } \\
700-850 \mathrm{~nm}\end{array}$ & $\begin{array}{l}\text { Addition of far-red light increased leaf area index; faster } \\
\text { growth may have caused decrease in dry weight content }\end{array}$ \\
\hline 5 & $\begin{array}{c}\text { Lettuce-Sunmang } \\
\text { seedlings from } 16 \text { days old }\end{array}$ & $\begin{array}{l}\text { Lee et al. } \\
(2016)\end{array}$ & $\begin{array}{l}\text { Far red, } \\
700-850 \mathrm{~nm}\end{array}$ & $\begin{array}{c}\text { Improved shoot and root growth; far-red LEDs improved } \\
\text { lettuce growth and bioactive compound content in a } \\
\text { closed-type plant production system }\end{array}$ \\
\hline 6 & Red lettuce-Sunmang & $\begin{array}{l}\text { Lee et al. } \\
(2015)\end{array}$ & $\begin{array}{l}\text { Far red, } \\
700-850 \mathrm{~nm}\end{array}$ & $\begin{array}{c}\text { The number of leaves increased, and the leaves were } \\
\text { longer; the results of this study suggest that the } \\
\text { supplementation with far-red LEDs should be considered } \\
\text { when designing artificial lighting systems for closed-type } \\
\text { plant factories }\end{array}$ \\
\hline 7 & $\begin{array}{c}\text { Lettuce-cultivars, red leaf } \\
\text { Sunmang and green leaf } \\
\text { Grand Rapid TBR, 18-day } \\
\text { seedlings for } 4 \text { weeks } \\
\end{array}$ & $\begin{array}{l}\text { Son and Oh, } \\
2015\end{array}$ & $\begin{array}{l}\text { Green, } \\
490-550 \mathrm{~nm}\end{array}$ & $\begin{array}{l}\text { The substitution of blue with green LEDs in the presence } \\
\text { of a fixed proportion of red enhanced growth of lettuce }\end{array}$ \\
\hline 8 & $\begin{array}{l}\text { Red leaf lettuce-cv. } \\
\text { 'Banchu Ref Fire' }\end{array}$ & $\begin{array}{c}\text { Johkan et al. } \\
\quad(2012)\end{array}$ & $\begin{array}{l}\text { Green, } \\
490-550 \mathrm{~nm}\end{array}$ & $\begin{array}{l}\text { High-intensity }\left(300 \mu \mathrm{mol} \mathrm{m}{ }^{-2} \mathrm{~s}^{-1}\right) \text { green LED light } \\
\text { promoted lettuce growth; } 510 \mathrm{~nm} \text { light had the greatest } \\
\text { effect on plant growth }\end{array}$ \\
\hline 9 & $\begin{array}{c}\text { Red leaf lettuce seedlings- } \\
\text { cv. 'Banchu Red Fire' }\end{array}$ & $\begin{array}{c}\text { Johkan et al. } \\
(2010)\end{array}$ & \begin{tabular}{|c|} 
Blue, \\
$425-490 \mathrm{~nm}$ \\
\end{tabular} & $\begin{array}{l}\text { Resulted in compact lettuce seedling morphology; } \\
\text { promoted the growth of lettuce after transplanting }\end{array}$ \\
\hline 10 & $\begin{array}{l}\text { Baby leaf lettuce-Red } \\
\text { Cross }\end{array}$ & $\begin{array}{c}\text { Li and } \\
\text { Kubota, } 2009\end{array}$ & $\begin{array}{c}\text { Far red, } \\
700-850 \mathrm{~nm}\end{array}$ & $\begin{array}{l}\text { The fresh weight, dry weight, stem length, leaf length, and } \\
\text { leaf width significantly increased by } 28 \%, 15 \%, 14 \%, 44 \% \text {, } \\
\text { and } 15 \% \text {, respectively, with supplemental FR light } \\
\text { compared to white light }\end{array}$ \\
\hline 11 & $\begin{array}{l}\text { Red leaf lettuce- } \\
\text { Outeredgeous }\end{array}$ & $\begin{array}{l}\text { Stutte et al. } \\
\qquad(2009)\end{array}$ & $\begin{array}{c}\text { Far red, } \\
700-850 \mathrm{~nm}\end{array}$ & $\begin{array}{c}\text { Leaf elongation; total dry weight of plants grown under } \\
\text { red LEDs alone was } \approx 20 \% \text { lower than that of plants with } \\
\text { blue or far red added }\end{array}$ \\
\hline 12 & $\begin{array}{l}\text { Red leaf lettuce-cv. } \\
\text { 'Outeredgeous' }\end{array}$ & $\begin{array}{l}\text { Stutte et al. } \\
\quad(2009)\end{array}$ & $\begin{array}{c}\text { Blue, } \\
425-490 \mathrm{~nm}\end{array}$ & $\begin{array}{l}\text { Leaf expansion; the addition of blue light allowed full } \\
\text { development of anthocyanin to occur }\end{array}$ \\
\hline
\end{tabular}


In an experiment conducted by Kim et al. (2021), 14 days after sowing, the combined effects of light intensity (photosynthetic photon flux density, PPFD: 100, 250, and $500 \mu \mathrm{mol} \mathrm{m} \mathrm{m}^{-2}$ ) and electrical conductivity (EC level: $0.8,1.4$, and $2.0 \mathrm{dS} \mathrm{m}^{-1}$ ) meant that the photosynthesis rate, stomatal conductance, transpiration rate, and water use efficiency of Indian lettuce increased as the light intensity increased. Considering the growth and functional material contents, the appropriate light intensity and EC level for the hydroponic cultivation of Indian lettuce are PPFD 500 with EC 2.0, and PPFD 100 and 250, which are lowlight conditions, under which EC 0.8 is suitable for growth. LED light with a blue light (B) and red light (R) combination (BR) has been widely used for horticultural crop production in controlled environments (Goto, 2012). BR (containing 5\% to $15 \% \mathrm{~B}$ ) at a PPFD of $\approx 300$ to $400 \mu \mathrm{mol} \mathrm{m} \mathrm{m}^{-2} \mathrm{~s}^{-1}$ and a photoperiod of $\approx 16 \mathrm{~h}$ appears to be optimal for the indoor production of microgreens based on crop yield and appearance quality (Ying et al., 2020). However, the impact of varying the proportions of these light qualities on the composition of diverse phytochemicals in indoor-grown microgreens is unclear (Ying et al., 2021).

Various studies show that lettuce microgreens contain higher quantities of phytonutrients and minerals and lower quantities of nitrates at the early stages of development than at the completely developed stage (Lester et al., 2010; Pinto et al., 2015). Thus, according to Ferron-Carrillo et al. (2021), consuming lettuce as microgreen lettuce may be preferable to consuming it at the baby leaf stage. Lettuce contains significant concentrations of carotenoids at the microgreen stage. The amounts of nitrate were lower at the microgreen stage than at the baby leaf stage, and the nitrate content was inversely correlated with the carotenoid content, which, in tissues, was higher at the microgreen stage and influenced by LEDs. Three different LED lamps were tested (Ferron-Carrillo et al., 2021): artificial white light, continuous light-emitting diodes with a longer blue wavelength, and continuous light-emitting diodes with a longer red wavelength. The accumulation of nitrates in plant tissues was clearly lower during the initial stages than during the final stages of crop development, ranging from 50.2 to $73.4 \mathrm{mg} 100 \mathrm{~g}^{-1}$ fresh weight for continuous light-emitting diodes with a longer red wavelength.

According to Zha et al. (2020), ascorbate tends to be present at higher levels in lettuce cultivated under LEDs supplying $75 \%$ blue and $25 \%$ red light relative to those delivering $25 \%$ blue and $75 \%$ red, and $50 \%$ blue and 50\% red light. Pre-harvest supplemental lighting using UV-A and blue or red/blue LED lighting can increase the growth and nutritional quality of lettuce grown hydroponically (Brazaityte et al., 2015; Verdaguer et al., 2017; Hooks et al., 2021). We can conclude that, by manipulating the colour of the lamps used, we can better support and direct the yield, growth, and nutrition of plants.

The photoperiodicity has a significant impact on the development of the lettuce crop, but for microgreens, good results have been obtained over very long periods of time: $12 / 12 \mathrm{~h}$ (day/night) (Paradiso et al., 2018; El-Nakhel et al., 2020) and 16/8 h (Ferron-Carrillo et al., 2021).

Lettuce microgreens are less demanding regarding temperature, requiring $20^{\circ} \mathrm{C}$ (Paradiso et al., 2018; Ferron-Carrillo et al., 2021) or a differentiated $24 / 18^{\circ} \mathrm{C}$ (light/dark) cycle (El-Nakhel et al., 2020).

A low relative air humidity reduces the risk of disease. For lettuce microgreens, the ideal humidity is $80 \%$ (Paradiso et al., 2018), 80-85\% (Ferron-Carrillo et al., 2021), or an alternating 65\%/80\% (light/dark) cycle (ElNakhel et al., 2020).

\section{Nutritional solution in the hydroponic system}

The nutritional solution in the hydroponic system must be carefully monitored, by checking certain essential parameters such as the $\mathrm{pH}$, electrical conductivity, dissolved oxygen, and temperature. The nutritional solution plays an important role in the growth and development of plants. We can note its composition for obtaining lettuce microgreens from the literature (Table 3). 
Table 3. The composition of the solution used to obtain lettuce microgreens

\begin{tabular}{|c|c|c|}
\hline No. & Authors & Description \\
\hline 1 & Hooks et al. (2021) & $\begin{array}{l}100 \mathrm{~N}, 20 \mathrm{P}, 129 \mathrm{~K}, 90 \mathrm{Ca}, 26 \mathrm{Mg}, 35 \mathrm{~S}, 1.3 \mathrm{Fe}, 0.21 \mathrm{~B}, 0.14 \mathrm{Mn}, 0.08 \mathrm{Zn}, 0.04 \mathrm{Cu}, \\
\text { and } 0.03 \mathrm{Mo} \mathrm{mg} \mathrm{L}^{-1} \text {; electrical conductivity of } 1.5 \mathrm{dS} \mathrm{m}^{-1} \text { and a pH of } 6.0\end{array}$ \\
\hline 2 & $\begin{array}{l}\text { Ferron-Carrillo et } \\
\text { al. }(2021)\end{array}$ & Standard nutrient solution, at $\mathrm{pH} 5.8$ and EC $2.2 \mathrm{dS} \mathrm{m}^{-1}$ \\
\hline 3 & $\begin{array}{c}\text { El-Nakhel et al. } \\
(2020)\end{array}$ & 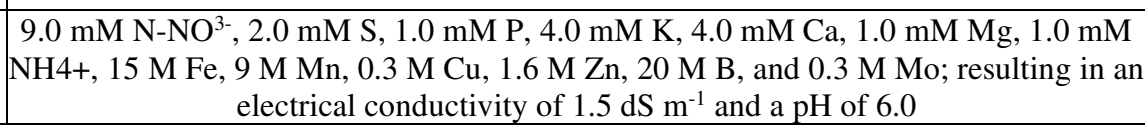 \\
\hline 4 & Renna et al. (2018) & $\begin{array}{c}119 \mathrm{~N}, 16 \mathrm{P}, 24 \mathrm{Mg}, 116 \mathrm{Ca}, 54 \mathrm{~S}, 1.12 \mathrm{Fe}, 0.27 \mathrm{Mn}, 0.13 \mathrm{Zn}, 0.27 \mathrm{~B}, 0.03 \mathrm{Cu} \text {, and } \\
0.01 \mathrm{Momg} \mathrm{L}^{-1} \text {; which resulted in an electrical conductivity of } 1.8 \mathrm{dS} \mathrm{m} \mathrm{m}^{-1} \text { and } \mathrm{pH} \text { of } \\
6.3\end{array}$ \\
\hline 5 & $\begin{array}{l}\text { Paradiso et al. } \\
\text { (2018) }\end{array}$ & $\begin{array}{c}105 \mathrm{~N}, 15 \mathrm{P}, 117 \mathrm{~K}, 100 \mathrm{Ca}, 24 \mathrm{Mg}, 0.25 \mathrm{~B}, 0.01 \mathrm{Cu}, 2.5 \mathrm{Fe}, 0.25 \mathrm{Mn}, 0.025 \mathrm{Zn} \text {, and } \\
0.005 \mathrm{Mo} \mathrm{mg} \mathrm{L}^{-1}\end{array}$ \\
\hline
\end{tabular}

A concentration of oxygen dissolved in water over $6 \mathrm{mg} \mathrm{O}_{2} \mathrm{~L}^{-1} \mathrm{~min}^{-1}$ prevents the development of disease in the nutritional solution (Msayleb, 2014). The nutritional solution must be maintained at a low temperature (under $20^{\circ} \mathrm{C}$ ) in order to maintain the quantity of oxygen dissolved in the water under optimal parameters $\left(6 \mathrm{mg} \mathrm{L}^{-1}\right)$.

Based on the literature analysed, Table 4 shows the average values for the growth and development of lettuce microgreens.

Table 4. Needs of lettuce microgreens grown in a hydroponic system

\begin{tabular}{|c|c|c|c|}
\hline No. & Parameter & Unit of measurement & Average value of parameter \\
\hline 1 & Light & $\mathrm{W}$ & 400 \\
\hline 1.1 & Photoperiodicity & $\mathrm{h}$ & $07: 00-20: 00(12 \mathrm{~h})$ \\
\hline 1.2 & Light intensity & $\mu \mathrm{molm}^{-2} \mathrm{~s}^{-1}$ & 400 \\
\hline 1.3 & Colour spectrum & $\mathrm{nm}$ & $440-460$ \\
\hline 1.4 & Position & $\mathrm{cm}$ & $\begin{array}{c}\text { 150-Lamps, HPS (high-pressure sodium) } \\
\text { 40-Lamps, LED }\end{array}$ \\
\hline 2 & Temperature & ${ }^{\circ} \mathrm{C}$ & $20 \pm 2$ \\
\hline 3 & Humidity & $\%$ & $80 \pm 5$ \\
\hline 4 & Nutrients & $\mathrm{N}-\mathrm{P}-\mathrm{K}: 3: 2: 3(5: 1: 5)$ & $6.3 \pm 0.4$ \\
\hline 5 & $\mathrm{pH}$ & $\mathrm{pH} \mathrm{units}$ & $1.8 \pm 0.2$ \\
\hline 6 & Electrical conductivity & $\mathrm{mS}^{-1}$ & 6 \\
\hline 7 & Dissolved oxygen & $\mathrm{mgL}^{-1}$ & $18 \pm 2$ \\
\hline 8 & Temperature & ${ }^{\circ} \mathrm{C}$ & \\
\hline
\end{tabular}

\section{Nutrient solution and production quality}

The mineral composition of microgreens can be modified through the solution used. Thus, for example, for people with impaired kidney function, small plants low in potassium can be obtained (Alvarado-Camarillo et al., 2020). Renna et al. (2018) used lettuce (cultivar Bionda da taglio) grown using a hydroponic system with different potassium $(\mathrm{K})$ levels $\left(0,29.1,58.4\right.$, and $\left.117 \mathrm{mg} \mathrm{L}^{-1}\right)$ in order to produce microgreens with a low potassium content. The $\mathrm{K}$ content in the microgreens was successfully reduced by using a nutrient solution,

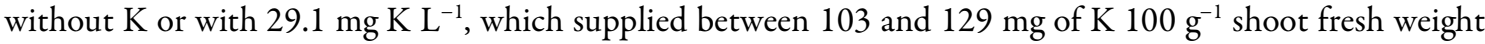
(about $7.7-8.6 \%$ of the daily $\mathrm{K}$ intake that was recommended for patients affected by chronic kidney disease).

The contents of nitrates in lettuce and other vegetables depends on several factors: the (i) variety (Sotelo et al., 2007), (ii) growing season (Ferron-Carrillo et al., 2021), (iii) wavelength of light received by the plant, (iv) crop system, and (v) fertigation (Urrestarazu et al., 1998). In 2011, the European Union regulated the maximum allowable concentrations as 500 and $400 \mathrm{mg} \mathrm{NO}_{3}^{-} 100 \mathrm{~g}^{-1}$ fresh weight for lettuce harvested in winter and spring, respectively, and $250 \mathrm{mg} \mathrm{NO}_{3}{ }^{-} 100 \mathrm{~g}^{-1}$ fresh weight for iceberg lettuce (ECR, 2011). 
By comparing the mineral, phytochemical, and antioxidant capacity attributes of two pigmented lettuce capitata cultivars (green and red Salanova) harvested at the microgreen and mature-leaf stages, El-Nakhel et al. (2020) obtained the following results:

- The calcium and magnesium were higher in microgreens irrespective of the cultivar; conversely, phosphorous, potassium, and nitrate were higher in mature leaves;

- All the pigments including chlorophyll, lutein, and beta-carotene increased at the advanced maturity stage and were more concentrated in the red-pigmented cultivar at both stages;

- The total polyphenols accumulated more densely in red Salanova, particularly in the microgreen stage, whereas, in green Salanova, the accumulation was significant but less pronounced in the microgreen stage;

- Chlorogenic acid, quercetin malonyl glucoside, rutin, and coumaroyl quinic acid were the most concentrated phenolic acids in microgreens, while feruloyl tartaric acid was predominant in mature leaves.

Pinto et al. (2015) and Weber (2016) obtained similar results by comparing the mature leaves of lettuce with lettuce microgreens and their respective mineral profiles. According to Pinto et al. (2015), microgreens possess higher contents of most minerals $\left(\mathrm{Ca}, \mathrm{Mg}, \mathrm{Fe}, \mathrm{Mn}, \mathrm{Zn}, \mathrm{Se}\right.$, and $\mathrm{Mo}$ ) and a lower $\mathrm{NO}_{3}{ }^{-}$content than mature lettuce. Consequently, microgreens can be considered a good source of minerals in the human diet (Elena and Ernst, 2015), and their consumption could be an important strategy for meeting children's dietary mineral requirements without exposing them to harmful $\mathrm{NO}_{3}{ }^{-}$. By using existing information on microgreens and the available technology, which is continually evolving, the range of natural products used for the treatment of many diseases can be enriched (Hossain, 2011).

Lettuce microgreens can be considered good sources of $\mathrm{Ca}$ and $\mathrm{K}$, and they also contain the highest levels of carotenoids. The microgreens also present higher amounts of tocopherol and carotenoids than mature vegetables (Kyriacou et al., 2016; Paradiso et al., 2018). In addition, the nutraceutical value of microgreens can be further improved through Se biofortification, delivering Se-enriched foods and, potentially, an enhanced content of bioactive compounds (Pannico et al., 2020). Improving the availability of Se to plants is, therefore, a potential pathway to overcoming human Se deficiencies (Hossain et al., 2021).

However, lettuce microgreens typically have a short shelf life due to rapid product deterioration (Mir et al., 2017). Due to their delicate tissues, fresh cut microgreens showed a shelf life not exceeding 10 days at $5{ }^{\circ} \mathrm{C}$ (Paradiso et al., 2018). Harvesting with the roots can help to retain the freshness of hydroponic lettuce (Suo et al., 2021); the optimal length of root retention for hydroponic lettuce was found to be $9 \mathrm{~cm}$. Changing the lettuce's characteristics through certain treatments such as light and allicin treatment can extend its shelf life (Peng et al., 2015; Ufuk and Rezzan, 2017).

The control of pathogens is a major issue for the lettuce microgreen crop. Hydrogen peroxide $\left(\mathrm{H}_{2} \mathrm{O}_{2}\right)$ is an oxidizing agent used to disinfect recirculated irrigation water during production. According to Eicher-Sodo et al. (2019), the maximum quantity that can be applied, without reducing the quality, aspect, and physiological growth is $125 \mathrm{mgL}^{-1}$ (Othilie), $75 \mathrm{mg} \mathrm{L}^{-1}$ (Rouxai), and $125 \mathrm{mg} \mathrm{L}^{-1}$ (Xandra). The lettuce microgreen hydroponic system uses less water due to the constant reuse of nutrient solution, and it also reduces the risk of soilborne diseases (Bevly et al., 2016). As there is the potential for phytopathogens to develop, it is very important to take measures during production to eliminate them (Aruscavage et al., 2008; D'Souza et al., 2015). Recent research shows the possibility of intervening before and after harvest, in the form of calcium treatments, active food packaging, and the control of temperature and light, in order to maintain the quality, increase the nutritional value, and extend the retail period (Dainelli et al., 2008; Chandra et al., 2012; Turner et al., 2020). 


\section{Conclusions}

Lettuce microgreens have interesting nutritional properties, mainly regarding their contents of mineral nutrients and bioactive compounds, and they have notable potential for improving the nutritional content of the human diet. Appropriate pre- and postharvest strategies should be developed, to allow lettuce microgreens to retain their nutritional value for as long as possible.

Hydroponic lettuce microgreens require the application of chemical nutritional solutions, which should meet the nutritional demands of plants according to their stages of development. In order to control any risk, the nutritional solution must be carefully monitored by checking essential parameters such as the $\mathrm{pH}$, electrical conductivity, temperature, and oxygen dissolved in water, as well as the environmental conditions of light (photoperiodicity, light intensity, colour spectrum, and position), temperature, and humidity. The optimal intervals for these parameters for hydroponic growth are different from those for classical soil growth.

Planting crops in protected environments together with hydroponic systems could lead to the establishment of protocols for cultivating microgreens that minimize factors that negatively influence plants, in order to obtain higher concentrations of active substances.

\section{Authors' Contributions}

TR: Writing - original draft; Conceptualization; Project administration; PIM: Writing - review and editing; Data curation; Investigation; OSM: Writing - review and editing; Data curation; Investigation;

All authors read and approved the final manuscript.

\section{Acknowledgements}

This work was supported by a grant of the Romanian National Authority for Scientific Research and Innovation, CCCDI-UEFISCDI, project number COFUND-ICT-AGRI-FOOD-GOHYDRO-2, within PNCDI III. GOhydro is part of the ERA-NET Cofund ICT-AGRI-FOOD with funding provided by national sources; the Executive Agency for Higher Education, Research, Development and Innovation Funding; and co-funding by the European Union's Horizon 2020 research and innovation program, Grant Agreement number 862665 .

\section{Conflict of Interests}

The authors declare that there are no conflicts of interest related to this article.

\section{References}

Alvarado-Camarillo D, Valdez-Aguilar LA, González-Fuentes JA, Rascón-Alvarado E, Peña-Ramos FM (2020). Response of hydroponic lettuce to aeration, nitrate and potassium in the nutrient solution. Acta Agriculturae Scandinavica, Section B - Soil and Plant Science 70(4):341-348. https://doi.org/10.1080/09064710.2020.1730430

Aruscavage D, Miller SA, Lewis Ivey ML, Lee K, LeJeune JT (2008). Survival and dissemination of Escherichia coli O157:H7 on physically and biologically damaged lettuce plants. Journal of Food Protection 71:2384-2388. https://doi.org/10.4315/0362-028X-71.12.2384 
Bevly MM, Martin MM, Puffy S, Dharini S (2016). Phytochemicals and overall quality of leafy lettuce (Lactuca sativa L.) varieties grown in closed hydroponic system. Journal of Food Quality 39:805-815. https://doi.org/10.1111/jfq.12234

Bian Z, Lei B, Chang R, Wang Y, Li T, Yang Q (2020). Selenium distribution and nitrate metabolism in hydroponic lettuce (Lactuca sativa L.): effects of selenium forms and light spectra. Journal of Integrative Agriculture 19:133144. https://doi.org/10.1016/S2095-3119(19)62775-9

Brazaitytė A, Viršilè A, Jankauskienė J, Sakalauskienè S, Samuolienė G, Sirtautas R, ... Duchovskis P (2015). Effect of supplemental UV-A irradiation in solid-state lighting on the growth and phytochemical content of microgreens. International Agrophysics 29(1):13-22. https://doi.org/10.1515/intag-2015-0004

Carvalho SD, Folta KM (2016). Green light control of anthocyanin production in microgreens. In: Currey CJ, Lopez RG, Runkle ES (Eds). Proceedings of the VIII International Symposium on Light in Horticulture. Acta Horticulturae 1134:13-18. https://doi.org/10.17660/ActaHortic.2016.1134.2

Chandra D, Kim JG, Kim YP (2012). Changes in microbial population and quality of microgreens treated with different sanitizers and packaging films. Horticulture, Environment, and Biotechnology 53:32-40. https://doi.org/10.1007/s13580-012-00756

Choe U, Yu LL, Wang TT (2018). The science behind microgreens as an exciting new food for the 21 st century. Journal of Agricultural and Food Chemistry 66:11519-11530. https://doi.org/10.1021/acs.jafc.8b03096

Ciofu R, Stan N, Popescu V, Chilom P, Apahidean S, Horgos A, Berar V, Lauer KF, Atanasiu N (2004). Vegetable treaty. Publisher Ceres Bucharest, pp 1882.

Ciuta F, Arghir LD, Tudor CA, Lagunovschi-Luchian V (2020). Research on microgreens farming in vertical hydroponic system. Journal of Horticulture, Forestry and Biotechnology 24(4):7-34.

Cruz R, Baptista P, Cunha S, Pereira JA, Casal S (2012). Carotenoids of lettuce (Lactuca sativa L.) grown on soil enriched with spent coffee grounds. Molecules 17:1535-1547. https://doi.org/10.3390/molecules 17021535

Dainelli D, Gontard N, Spyropoulos D, Zondervan-van den Beuken E, Tobback P (2008). Active and intelligent food packaging: Legal aspects and safety concerns. Trends in Food Science and Technology 19(S1):S103-S112. https://doi.org/10.1016/j.tifs.2008.09.011

D'Souza C, Yuk HG, Khoo GH, Zhou W (2015). Application of light-emitting diodes in food production, postharvest preservation, and microbiological food safety. Comprehensive Reviews in Food Science and Food Safety 14:719740. https://doi.org/10.1111/1541-4337.12155

Dupont S, Mondi Z, Willamson G, Price K (2000). Effect of variety, processing, and storage on the flavonoid glycoside and composition of lettuce and chicory. Journal of Agricultural and Food Chemistry 48(9):3957-3964. https://doi.org/10.1021/jf0002387

ECR (2011). European Commission Regulation, No. 1258/2011 of 2 December 2011 amending Regulation No. $1881 / 2006$ as regards maximum levels for nitrates in foodstuffs. Official Journal of the European Union, L 320: 15-17.

Eicher-Sodo M, Gordon R, Zheng YB (2019). Characterizing the phytotoxic effects of hydrogen peroxide on common microgreen species and lettuce cultivars. Horttechnology 29(3):283-289. https://doi.org/10.21273/HORTTECH04255-18

Elena T, Ernst J (2015). Nitric oxide prevents wound-induced browning and delays senescence through inhibition of hydrogen peroxide accumulation in fresh-cut lettuce. Innovative Food Science and Emerging Technologies 30:157-169. https://doi.org/10.1016/j.ifset.2015.06.001

Ferron-Carrillo F, Guil-Guerrero JL, Gonzalez-Fernandez MJ, Lyashenko S, Battafarano F, da Cunha-Chiamolera TPL, Urrestarazu M (2021). LED enhances plant performance and both carotenoids and nitrates profiles in lettuce. Plant Foods for Human Nutrition. https://doi.org/10.1007/s11130-021-00894-8

Ghoora MD, Haldipur AC, Srividya N (2020). Comparative evaluation of phytochemical content, antioxidant capacities and overall antioxidant potential of select culinary microgreens. Journal of Agriculture and Food Research 2:100046. https://doi.org/10.1016/j.jafr.2020.100046

Giurgiu GM (2016). Research on hydroponic cultivation of some medicinal and aromatic plant species and the influence of the technology on the bioactive substance. Doctoral Thesis, USAMV Cluj-Napoca.

Goto E (2012). Plant production in a closed plant factory with artificial lighting. Acta Horticulturae 956:37-49. https://doi.org/10.17660/ActaHortic.2012.956.2 
Güzel ME, Coşkunçelebi K, Kilian N, Makbul S, Gültepe M (2021). Phylogeny and systematics of the Lactucinae (Asteraceae) focusing on their SW Asian centre of diversity. Plant Systematics and Evolution 307:7. https://doi.org/10.1007/s00606-020-01719-y

Hajihashemi S, Skalicky M, Brestic M, Pavla V (2020). Cross-talk between nitric oxide, hydrogen peroxide and calcium in salt-stressed Chenopodium quinoa Willd. at seed germination stage. Plant Physiology and Biochemistry 154: 657-664. https://doi.org/10.1016/j.plaphy.2020.07.022

Hayden A (2006). Aeroponic and hydroponic systems for medicinal herb, rhizome, and root crops. HortScience 41(1):36538. https://doi.org/10.21273/HORTSCI.41.3.536

Hegarty TW, Ross HA (2006). Effects of light and growth regulators on germination and radicle growth of lettuce seed held under high temperature stress and water stress. New Phytologist 82(1):49-57. https://doi.org/10.1111/j.1469-8137.1979.tb07559.x

Hiroshi I (1964). The effects of temperature on the germination and radicle growth of photosensitive lettuce seed. Plant Cell Physiology 5(4):429-439.

Hooks T, Masabni J, Sun L, Niu G (2021). Effect of pre-harvest supplemental UV-A/blue and red/blue LED lighting on lettuce growth and nutritional quality. Horticulturae 7(4):80. https://doi.org/10.3390/horticulturae7040080

Hossain A, Skalicky M, Brestic M, Maitra S, Sarkar S, Ahmad Z, ... Laing AM (2021). Selenium biofortification: roles, mechanisms, responses and prospects. Molecules 26(4):881. https://doi.org/10.3390/molecules26040881

Hossain MM (2011). Therapeutic orchids: Traditional uses and recent advances - An overview. Fitoterapia 82:102-140. https://doi.org/10.1016/j.fitote.2010.09.007

Isah T, Umar S, Mujib A, Sharma MP, Rajasekharan PE, Zafar N, Frukh A (2018). Secondary metabolism of pharmaceuticals in the plant in vitro cultures: strategies, approaches, and limitations to achieving higher yield. Plant Cell Tissue and Organ Culture 132(13): 239-265. https://doi.org/10.1007/s11240-017-1332-2

Johkan M, Shoji K, Goto F, Hashida SN, Yoshihara T (2010). Blue light-emitting diode light irradiation of seedlings improves seedling quality and growth after transplanting in red leaf lettuce. HortScience 45(12):1809-1814. https://doi.org/10.21273/HORTSCI.45.12.1809

Kim MJ, Moon Y, Tou JC, Mou B, Waterland NL (2016). Nutritional value, bioactive compounds and health benefits of lettuce (Lactuca sativa L.). Journal of Food Composition and Analysis 49:19-34. https://doi.org/10.1016/j.jfca.2016.03.004

Kim JK, Jang DC, Kang HM, Nam KJ, Lee MH, Na JK, Choi KY (2021). Effects of light intensity and electrical conductivity level on photosynthesis, growth and functional material contents of Lactuca indica L. 'Sunhyang' in Hydroponics. Journal of Bio-Environment Control 30(1):1-9. https://doi.org/10.12791/KSBEC.2021.30.1.001

Kyriacou MC, Rouphael Y, Di Gioia F, Kyratzis A, Serio F, Renna M, De Pascale S, Santamaria P (2016). Micro-scale vegetable production and the rise of microgreens. Trends in Food Science and Technology 57:103-115. https://doi.org/10.1016/j.tifs.2016.09.005

Lebeda A, Ryder EJ, Grube R, Dolezalov AI, Kristkova E (2007). Lettuce (Asteracease; Lactuca spp.). Singh RJ (Ed). Genetic Resources, Chromosome Engineering, and Crop Improvement. Vol. 3, Vegetable Crops, CRC Press, Tailor and Francis Group, Boca Raton, Florida, USA, pp 377-472.

Lee MJ, Son KH, Oh MM (2016). Increase in biomass and bioactive compounds in lettuce under various ratios of red to far-red LED light supplemented with blue LED light. Horticulture, Environment, and Biotechnology 57(2):139147. https://doi.org/10.1007/s13580-016-0133-6

Lee MJ, Park SY, Oh MM (2015). Growth and cell division of lettuce plants under various ratios of red to far-red lightemitting diodes. Horticulture, Environment, and Biotechnology 56(2):186-194. https://doi.org/10.1007/s13580-015-0130-1

Legendre R, van Iersel MW (2021). Supplemental far-red light stimulates lettuce growth: disentangling morphological and physiological effects. Plants 10(1):166. https://doi.org/10.3390/plants10010166

Lenzi A, Orlandini A, Bulgari R, Ferrante A, Bruschi P (2019). Antioxidant and mineral composition of three wild leafy species: A comparison between microgreens and baby greens. Foods 8(10):487. https://doi.org/10.3390/foods8100487

Lester GE, Hallman GJ, Pérez JA (2010). Gamma-irradiation dose: effects on baby-leaf spinach ascorbic acid, carotenoids, folate, $\alpha$-tocopherol, and phylloquinone concentrations. Journal of Agricultural and Food Chemistry 58(8):49014906. https://doi.org/10.1021/jf100146m

Li Q, Kubota C (2009). Effects of supplemental light quality on growth and phytochemicals of baby leaf lettuce. Environmental and Experimental Botany 67(1):59-64. https://doi.org/10.1016/j.envexpbot.2009.06.011 
Li Z, Zhao X, Sandhu AK, Gu L (2010). Effects of exogenous abscisic acid on yield, antioxidant capacities, and phytochemical contents of greenhouse grown lettuces. Journal of Agricultural and Food Chemistry 58:6503-6509. https://doi.org/10.1021/jf1006962

Lin KH, Huang MY, Huang WD, Hsu MH, Yang ZW, Yang CM (2013). The effects of red, blue, and white lightemitting diodes on the growth, development, and edible quality of hydroponically grown lettuce (Lactuca sativa L. Var. Capitata). Scientia Horticulturae 150:86-91. https://doi.org/10.1016/j.scienta.2012.10.002

Liorach R, Martínez-Sánchez A, Tomás-Barberán FA, Gil MI, Ferreres F (2008). Characterisation of polyphenols and antioxidant properties of five lettuce varieties and escarole. Food Chemistry 108(3):1028-1038. https://doi.org/10.1016/j.foodchem.2007.11.032

Mbarki S, Skalicky M, Vachova P, Hajihashemi S, Jouini L, Zivcak M, ... Zoghlami Khelil A (2020). Comparing salt tolerance at seedling and germination stages in local populations of Medicago ciliaris L. to Medicago intertexta L. and Medicago scutellata L. Plants 9(4):526. https://doi.org/10.3390/plants9040526

McGehee CS, Raudales RE, Elmer WH, McAvoy RJ (2019). Efficacy of biofungicides against root rot and damping-off of microgreens caused by Pythium spp. Crop Protection 121:96-102. https://doi.org/10.1016/j.cropro.2018.12.007

Mir SA, Shah MA, Mir MM (2017). Microgreens: Production, shelf life, and bioactive components. Critical Reviews in Food Science and Nutrition 57(12):2730-2736. https://doi.org/10.1080/10408398.2016.1144557

Misra GM (2020). Food safety risk in an indoor microgreen cultivation system. Graduate Theses and Dissertations Retrieved from https://scholarworks.uark.edu/etd/3563

Mou B, Ryder E (2004). Relationship between the nutritional value and the head structure of lettuce. Acta Horticulturae 637:361-367. https://doi.org/10.17660/ActaHortic.2004.637.45

Mou B (2008). Lettuce. Prohens J, Nuez F (Eds). Handbook of Plant Breeding, Vol. I: Vegetables I: Asteraceae, Brassicaceae, Chenopodicaceae, and Cucurbitaceae, Springer, New York, NY, USA, pp 75-116.

Msayleb N (2014). Soil ozonation as a sustainable alternative to methyl bromide fumigation and synthetic pesticides. Graduate Theses and Dissertations. Paper 13763. https://doi.org/10.31274/etd-180810-408

El-Nakhel C, Pannico A, Graziani G, Kyriacou MC, Giordano M, Ritieni A, De Pascale S, Rouphael Y (2020). Variation in macronutrient content, phytochemical constitution and in vitro antioxidant capacity of green and red butterhead lettuce dictated by different developmental stages of harvest maturity. Antioxidants 9(4):300. https://doi.org/10.3390/antiox9040300

Ohashi-Kaneko K, Takase M, Kon N, Fujiwara K, Kurata K (2007). Effect of light quality on growth and vegetable quality in leaf lettuce, spinach and komatsuna. Environmental Control in Biology 45(3):189-198. https://doi.org/10.2525/ecb.45.189

Ojeda AD, Ligarreto GA, Martínez O (2012). Effects of environmental factors on the morphometric characteristics of cultivated lettuce (Lactuca sativa L.). Agronomía Colombiana 30(3):351-358.

Olle M, Alsiòa I (2019). Influence of wavelength of light on growth, yield and nutritional quality of greenhouse vegetables. Proceedings of the Latvian Academy of Sciences. Section B, Vol. 73, No. 1 (718), pp 1-9. https://doi.org/10.2478/prolas-2019-0001

Paradiso VM, Castellino M, Renna M, Gattullo CE, Calasso M, Terzano R, Allegretta I, Leoni B, Caponio F, Santamaria P (2018). Nutritional characterization and shelf-life of packaged microgreens. Food and Function 9(11):56295640. https://doi.org/10.1039/c8fo01182f

Pannico A, El-Nakhel C, Graziani G, Kyriacou MC, Giordano M, Soteriou GA, Zarrelli A, ... Rouphael Y (2020). Selenium biofortification impacts the nutritive value, polyphenolic content, and bioactive constitution of variable microgreens genotypes. Antioxidants 9:272. https://doi.org/10.3390/antiox9040272

Park CH, Yeo HJ, Baskar TB, Kim JK, Park SU (2018). Metabolic profiling and chemical-based antioxidant assays of green and red lettuce (Lactuca sativa). Natural Product Communications 13(3):315-322. https://doi.org/10.1177/1934578X1801300313

Peng X, Yang J, Cui P, Chen F, Fu Y, Hu Y, Zhang Q, Xia X (2015). Influence of allicin on quality and volatile compounds of fresh-cut stem lettuce during cold storage. LWT - Food Science and Technology (Lebensmittel-Wissenschaft Technol.) 60:300-307. https://doi.org/10.1016/j.1wt.2014.09.048

Pepe G, Sommella E, Manfra M, De Nisco M, Tenore GC, Scopa A, ... Campiglia P (2015). Evaluation of antiinflammatory activity and fast UHPLC-DAD-IT-TOF profiling of polyphenolic compounds extracted from green lettuce (Lactuca sativa L.; var. Maravilla de Verano). Food Chemistry 167:153-161. https://doi.org/10.1016/j.foodchem.2014.06.105 
Pinho P, Jokinen K, Halonen L (2017). The influence of the LED light spectrum on the growth and nutrient uptake of hydroponically grown lettuce. Lighting Research and Technology 49(7):866-881. https://doi.org/10.1177/1477153516642269

Pinto E, Almeida AA, Aguilar AA, Ferreira I (2015). Comparison between the mineral profile and nitrate content of microgreens and mature lettuces. Journal of Food Composition and Analysis 37:38-43. https://doi.org/10.1016/j.jfca.2014.06.018

Reed E, Ferreira CM, Bell R, Brown EW, Zheng J (2018). Plant-microbe and abiotic factors influencing Salmonella survival and growth on alfalfa sprouts and $S_{w i s s}$ chard microgreens. Applied and Environmental Microbiology, 84(9):e02814-17. https://doi.org/10.1128/AEM.02814-17

Renna M, Castellino M, Leoni B, Paradiso VM, Santamaria P (2018). Microgreens production with low potassium content for patients with impaired kidney function. Nutrients 10(6):675. https://doi.org/10.3390/nu10060675

Rodenburg CM (1960). Varieties of lettuce - an international monograph. Tjeenk Willink, Zwolle W.E.J.

Romani A, Pinelli P, Galardi C, Sani G, Cimato A, Heimler D (2002). Polyphenols in greenhouse and open-air-grown lettuce. Food Chemistry 79(3):337-342. https://doi.org/10.1016/S0308-8146(02)00170-X

Ryder EJ (1997). Compendium of lettuce diseases. Davis RM, Subbarao KV, Raid RN, Kurtz EA (Eds). APS Press, Saint Paul, Minnesota, pp 1-8.

Samuoliene G, Brazaityte A, Virsile A, Jankauskiene J, Sakalauskiene S, Duchovskis P (2016). Red light-dose or wavelength-dependent photoresponse of antioxidants in herb microgreens. Plos One 11(9):e0163405. https://doi.org/10.1371/journal.pone.0163405

Samuolienė G, Viršilè A, Brazaitytė A, Jankauskienė J, Sakalauskienė S, Vaštakaitė V, ... Duchovskis P (2017). Blue light dosage affects carotenoids and tocopherols in microgreens. Food Chemistry 228:50-56. https://doi.org/10.1016/j.foodchem.2017.01.144

Sergejeva D, Alsina I, Duma M, Dubova L, Augspole I, Erdberga I, Berzina K (2018). Evaluation of different lighting sources on the growth and chemical composition of lettuce. Agronomy Research 16(3):892-899. http://dx.doi.org/10.15159/ar.18.133

Sheikh BA (2006). Hydroponics: Key to sustain agriculture in water stressed and urban environment. Pakistan Journal of Agriculture, Agricultural Engineering and Veterinary Sciences 22(2):53-57.

Sofo A, Lundegårdh B, Mårtensson A, Manfra M, Pepe G, Sommella E, De Nisco M, Tenore GC, Campiglia P, Scopa A (2016). Different agronomic and fertilization systems affect polyphenolic profile, antioxidant capacity and mineral composition of lettuce. Scientia Horticulturae 204:106-115. http://dx.doi.org/10.1016/j.scienta.2016.04.003

Son KH, Oh MM (2015). Growth, photosynthetic and antioxidant parameters of two lettuce cultivars as affected by red, green, and blue light-emitting diodes. Horticulture, Environment, and Biotechnology 56(5):639-653. https://doi.org/10.1007/s13580-015-1064-3

Sotelo A, López-García S, Basurto-Peña F (2007). Content of nutrient and antinutrient in edible flowers of wild plants in Mexico. Plant Foods for Human Nutrition 62(3):133-138. https://doi.org/10.1007/s11130-007-0053-9

Stutte GW, Edney S, Skerritt T (2009). Photoregulation of bioprotectant content of red leaf lettuce with light-emitting diodes. HortScience 44(1):79-82. https://doi.org/10.21273/HORTSCI.44.1.79

Sung Y, Cantliffe DJ, Nagata RT (1997). Structural changes in lettuce seed during germination altered by genotype, seed maturation temperature and priming. HortScience 32(3):526E-527. https://doi.org/10.21273/HORTSCI.32.3.526E

Suo R, Wang W, Ma Y, Fu L, Cui Y (2021). Effect of different root lengths for retaining freshness of hydroponic lettuce. Journal of Agriculture and Food Research 4:100151. https://doi.org/10.1016/j.jafr.2021.100151

Takeba GO, Matsubara S (1976). Analysis of temperature effect on the germination of New York lettuce seeds. Plant Cell Physiology 17(1):91-101.

Takaki M, Zaia VM (1984). Effect of light and temperature on the germination of lettuce seeds. Planta 160(2):190-192.

Teng J, Liao P, Wang M (2021). The role of emerging micro-scale vegetables in human diet and health benefits - an updated review based on microgreens. Food and Function 12:1914-1932. https://doi.org/10.1039/DOFO03299A

Treadwell DD, Hochmuth RC, Simonne EH, Sargent SA, Davis LL, Laughlin WL, Berry A (2011). Organic fertilization programs for greenhouse fresh-cut basil and spearmint in a soilless media trough system. HortTechnology 21(2):162-169. https://doi.org/10.21273/HORTTECH.21.2.162

Turner ER, Luo Y, Buchanan RL (2020). Microgreen nutrition, food safety, and shelf life: A review. Journal of Food Science 85(4):870-882. https://doi.org/10.1111/1750-3841.15049 
Ufuk MK, Rezzan K (2017). While continuous white LED lighting increases chlorophyll content (Spad), green LED light reduces the infection rate of lettuce during storage and shelf-life conditions. Journal of Food Processing and Preservation 41:e13266. https://doi.org/10.1111/jfpp.13266

Urrestarazu M, Postigo A, Salas MC, Sánchez A, Carrasco G (1998). Nitrate accumulation reduction using chloride in the nutrient solution on lettuce growing by NFT in semiarid climate conditions. Journal of Plant Nutrition 21:1705-1714. https://doi.org/10.1080/01904169809365515

Urrestarazu M, Nájera C, Gea MM (2016). Effect of the spectral quality and intensity of light-emitting diodes on several horticultural crops. HortScience 51(3):268-271. https://doi.org/10.21273/HORTSCI.51.3.268

Van Treuren R, van Eekelen HDLM, Wehrens R, de Vos RCH (2018). Metabolite variation in the lettuce gene pool: towards healthier crop varieties and food. Metabolomics 14:146. https://doi.org/10.1007/s11306-018-1443-8

Verdaguer D, Jansen MA, Llorens L, Morales LO, Neugart S (2017). UV-A radiation effects on higher plants: Exploring the known unknown. Plant Science 255:72-81. https://doi.org/10.1016/j.plantsci.2016.11.014

Viršilè A, Brazaitytė A, Vaštakaitè-Kairienė V, Miliauskienė J, Jankauskienė J, Novičkovas A, Laužikè K, Samuolienė G (2020). The distinct impact of multi-color LED light on nitrate, amino acid, soluble sugar and organic acid contents in red and green leaf lettuce cultivated in controlled environment. Food Chemistry 310:125799. https://doi.org/10.1016/j.foodchem.2019.125799

Weber CF (2016). Nutrient content of cabbage and lettuce microgreens grown on vermicompost and hydroponic growing pads. Journal of Horticulture 3(4):1-5. https://doi.org/10.4172/2376-0354.1000190

Xiao Z, Lester GE, Luo Y, Wang Q (2012). Assessment of vitamin and carotenoid concentrations of emerging food products: edible microgreens. Journal of Agricultural and Food Chemistry 60(31):7644-7651. https://doi.org/10.1021/jf300459b

Ying Q, Jones-Baumgardt C, Zheng Y (2021). The proportion of blue light from light-emitting diodes alters microgreen phytochemical profiles in a species-specific manner. HortScience 56(1):13-20. https://doi.org/10.21273/HORTSCI15371-20

Ying Q, Kong Y, Zheng Y (2020). Growth and appearance quality of four microgreen species under light-emitting diode lights with different spectral combinations. HortScience 55(9):1399-1405, https://doi.org/10.21273/HORTSCI14925-20

Yuyao K, Krishna N (2021). Blue and far-red light affect area and number of individual leaves to influence vegetative growth and pigment synthesis in lettuce. Frontiers in Plant Science 12:1375. https://doi.org/10.3389/fpls.2021.667407

Zha L, Liu W, Yang Q, Zhang Y, Zhou C, Shao M (2020). Regulation of ascorbate accumulation and metabolism in lettuce by the red: blue ratio of continuous light using LEDs. Frontiers in Plant Science 11:704. https://doi.org/10.3389/fpls.2020.00704

Zheljazkov VD, Astatkie T, Hristov AN (2012). Lavender and hyssop productivity, oil content, and bioactivity as a function of harvest time and drying. Industrial Crops and Products 36(1):222-228. https://doi.org/10.1016/j.indcrop.2011.09.010

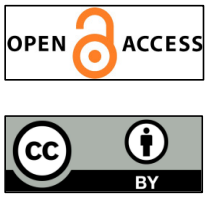

The journal offers free, immediate, and unrestricted access to peer-reviewed research and scholarly work. Users are allowed to read, download, copy, distribute, print, search, or link to the full texts of the articles, or use them for any other lawful purpose, without asking prior permission from the publisher or the author. License - Articles published in Notulae Botanicae Horti Agrobotanici Cluj-Napoca are Open-Access, distributed under the terms and conditions of the Creative Commons Attribution (CC BY 4.0) License. (c) Articles by the authors; UASVM, Cluj-Napoca, Romania. The journal allows the author(s) to hold the copyright/to retain publishing rights without restriction. 